\title{
Lockdowns, Quarantines, And Travel Restrictions, During COVID And Beyond: What's The Law, And How Should We Decide?
}

Lawrence O. Gostin

Georgetown University - Law Center - O'Neill Institute for National and Global Health Law, gostin@law.georgetown.edu

Meryl Chertoff

Georgetown University Law Center, mjc87@law.georgetown.edu

This paper can be downloaded free of charge from:

https://scholarship.law.georgetown.edu/facpub/2375

https://ssrn.com/abstract=3828179

Health Affairs Blog, March 24, 2021.

This open-access article is brought to you by the Georgetown Law Library. Posted with permission of the author. Follow this and additional works at: https://scholarship.law.georgetown.edu/facpub

Part of the Health Law and Policy Commons, and the International Humanitarian Law Commons 


\title{
Lockdowns, Quarantines, And Travel Restrictions, During COVID And Beyond: What's The Law, And How Should We Decide?
}

\author{
Lawrence O. Gostin and Meryl Justin Chertoff
}

The COVID-19 pandemic ushered in vast deprivations of liberty previously unthinkable: lockdowns, business closures, travel restrictions, and quarantines. Even witnessing China's January 2020 lockdown of 11 million people in Wuhan, it seemed wholly implausible that London, Rome, or New York would shut down. But they did, and much more. At the initial height of the pandemic in April 2020, more than 3.9 billion people, about half the world's population, were under stay-at-home orders. That same month, 43 US states were under stay-athome orders.

What are the scientific, public health, and ethical justifications for various forms of liberty deprivations? Are they lawful? Which branch, or level, of government holds the power to deprive individuals of freedom and the right to travel? What principles and policy mechanism can we establish to do a better job of protecting both liberty and public health during future emergencies?

International Travel Restrictions: Are they Lawful?

Currently, 49 countries completely bar international travel, while myriad others restrict travel to, or from, certain countries or regions. Even "open" countries often place barriers to travel, such as requiring testing or quarantine. The Biden Administration has signaled an aggressive strategy, characterizing the fight against COVID-19 as a "war". To tame concerning variants of SARSCoV-2, the novel coronavirus that causes COVID-19, the White House has tightened international travel restrictions, and was reported to have considered domestic travel restrictions.

\section{The WHO International Health Regulations}

The World Health Organization's (WHO) International Health Regulations (IHR) have been characterized as a "balancing dynamic", weighing public health against travel, trade and human rights. The IHR grant WHO the power to declare a public health emergency of international concern (PHEIC), and it has done so six times-for H1N1, Ebola (twice), Zika virus, polio, and COVID-19. WHO has recommended against travel and trade restrictions during every PHEIC.

Global public health policy experts believe the threat of travel restrictions and their economic impact deters states from early reporting of novel outbreaks, delaying the global response. Travel restrictions also can be self-defeating, impeding public health and humanitarian supplies and assistance. During the COVID-19 pandemic, WHO has largely reinforced its historic antipathy to travel restrictions. And as in many past emergencies, governments widely disregarded WHO's advice.

Governments, including that of the U.S., have ignored WHO or relied on the considerable leeway the IHR provide to restrict travel. Article 31, for example, allows states parties to require 
"proof of vaccination or other prophylaxis", including to determine whether a public health risk exists. Although silent on complete travel bans, the regulations probably do allow them, as well as impediments to travel like testing or quarantine.

With the emergence of COVID-19, virtually all governments imposed international travel restrictions. Governments and airlines are now actively considering vaccination "passports" for travel and other activities. But does the science support the position that international travel restrictions actually prevent the cross-border spread of disease? Article 43 of the IHR requires nations to base decisions on scientific evidence concerning risks to human health as well as WHO guidance.

Prevailing scientific thought has been that international travel restrictions might give governments a little time (maybe just weeks) to prepare, but beyond that are ineffective at preventing disease spread. Certainly, restrictions can be effective in island nations like Australia or New Zealand. But with ubiquitous international travel routes, stopping a virus from entering, say, New York, Buenos Aires, or London is considerably harder.

In truth, however, WHO's opposition to travel restrictions has mostly been evidence-free. We don't truly know if travel restrictions are effective and, if so, under what circumstances. Going forward, it's vital to study and better understand the impacts of travel restrictions on epidemic response. That is, are travel restrictions a useful public health tool and, if so, under what circumstances are they justified? It would be unacceptable, and possibly unlawful, to make such consequential decisions in the absence of evidence.

\section{The Constitution And CDC Regulations: Federal Control At The Zenith}

Turning to US law, our Constitution (Art I, Sec 8) grants Congress sole power "to regulate Commerce with foreign Nations, and among the several States, and with Indian Tribes." Although the federal government has wide authority to manage international relations and control the border, states exercise public health (police) powers within their territories, a key characteristic of American federalism.

Foreign nationals who do not have permanent residence or other special status have no right to travel to the US. The Surgeon General, through the Centers for Disease Control and Prevention (CDC), is explicitly empowered to bar entry of foreign nationals to prevent the introduction of infectious diseases. Currently, the Centers for Disease Control and Prevention (CDC) publishes a comprehensive list of travelers barred from entry to the United States. Enforcement tools are broad: travelers can be forced to return to their point of embarkation; passengers with symptoms can be isolated; and those exposed can be quarantined.

While US citizens cannot be permanently barred from reentry, they can be isolated or quarantined at points of entry. Exercising powers under the 1944 US Public Health Services Act, in the early weeks of the COVID-19 pandemic, the CDC quarantined or isolated travelers returning from China and those stranded on cruise carriers. These actions were consistent with earlier court cases, which upheld federal powers to quarantine or isolate returning travelers potentially exposed to smallpox or diagnosed with $\underline{\text { drug-resistant tuberculosis. }}$. 
The Biden Administration acted swiftly to further limit travel after the new COVID-19 variants emerged, but the restrictions are in a grey area of legality because they act on American citizens in foreign countries. On January 26, 2021, the State Department ordered all inbound international travelers to produce proof of a negative SARS-CoV-2 test performed up to three days prior to boarding a US-bound flight, or to prove recovery from infection. Passengers, including US citizens, failing to provide documentation are barred from boarding. The Administration also consulted airlines about requiring SARS-CoV-2 testing on domestic flights but no agency has since issued a rule.

The new rule on international flights raises a civil liberties red flag. This may be the first time the CDC has required testing (and possible isolation or quarantine) extraterritorially. It is a marked departure from standard policy and practice of allowing entry to US citizens. During the 2014 West African Ebola epidemic, for example, US citizens exposed to Ebola virus disease were permitted entry to the US, but subject to quarantine upon arrival. While referencing compassionate financial assistance for citizens stranded abroad, the new directive represents a significant change to repatriation norms for US citizens. Still, the CDC views the directive as "delaying" rather than "banning" entry of US nationals.

Though legally questionable, testing at the point of departure may be sound scientifically. It has distinct public health benefits as it helps protect against transmission to fellow passengers and airline personnel. Testing or quarantine at a US point of entry would still entail risks incurred on the flight and may thus be less preferable from a public health standpoint.

\section{State Travel Restrictions On Returning US Citizens}

The view that the federal government, not US states, is supreme in regulating international travel oversimplifies the intertwined jurisdictional elements of modern travel. The CDC controls travel into an air, sea, or land port of entry, and has power to quarantine the traveler upon arrival. But as soon as the traveler exits passport control, she is subject to state jurisdiction, and states may attempt to impose restrictions beyond those imposed by the federal government.

That is what happened to Kaci Hickox, a nurse who traveled to Sierra Leone to treat Ebola patients in 2014. Hickox was subject only to voluntary quarantine rules issued by the Obama Administration to encourage health workers to "put out the blaze" in the hot zone. Two state governors - New Jersey's Chris Christie and Maine's Paul LePage --disagreed with federal policy and detained the public health nurse against her will when she entered their states.

She sued on constitutional grounds. While the suits were settled, the conflict demonstrates one of the flaws of in unmediated conflict between federal and state policy during public health emergencies. For the most part, federal guidance is less politicized than state rules, which can contain more performative elements, like Christie's "tough on Ebola" stance in an election year. This is not always the case though, as U.S. Representative Kevin McCarthy's (R-

CA) remarks last week during a border visit show-McCarthy trotted out the old stereotype of refugees and migrants as carriers of disease.

Domestic Considerations: The Right To Interstate Travel And Privileges And Immunities 
While governing international travel is complex, our system of dual sovereignty makes governing interstate travel especially convoluted. The "right to travel" encompasses several rights. Historically citizens have had the right to move freely between the states. During the Great Depression, the Supreme Court struck down California's law barring residence for "Okies"-farmers whose flight from the Dust Bowl was told by John Steinbeck in The Grapes of Wrath. In 1999, the Court said, "free ingress and regress to and from neighboring states" dates back to the Articles of Confederation, but the Justices didn't specify where the right resides in the Constitution.

Second, Article IV of the Constitution provides citizens of one state with same "privileges and immunities" of a citizen of the state to which she is visiting. It protects the right to enter and to leave another state, and to be treated equally. States, therefore, cannot discriminate between instate and out-of-state residents; they cannot grant more privileges to the former than the latter. That is why most state travel restrictions apply equally to in-state and out-of-state residents seeking to enter the state border.

Finally, under American federalism, Congress has sole power to regulate interstate commerce. The so-called "dormant" Commerce Clause prohibits states from restricting the free flow of people and goods among the states. Taken as a whole, neither the federal government nor the states can bar interstate travel.

\section{Epidemic Disease: An Exception to the Right to Interstate Travel}

Despite the general rules noted above, judicial recognition of state "police power" to impose quarantines dates back at least to 1824. In Compagnie Francaise de Navigation (1902), the Supreme Court upheld a New Orleans ordinance prohibiting all domestic and foreign travelersregardless of health status - from entering the city due to a yellow fever outbreak, stressing that the constitutionality of state quarantines was "not an open question" even where they burden interstate commerce. In addition to state powers, cities with powers delegated to them by their state, like San Francisco and New York City also exercise police powers with respect to "essential" matters of public health. Science and fair treatment cabin the exercise of those powers.

During the COVID-19 pandemic, nearly half the states have imposed testing or quarantine requirements on individuals traveling from other states. Most specify only voluntary selfquarantine of interstate travelers, yet the state retains the power to order quarantine. Some states use another model, requiring proof of a negative SARS-CoV-2 test within three days of travel. Thus far during the current pandemic, courts have not struck down these impediments to travel, probably for two reasons: 1) quarantines of interstate travelers do not bar entry into the state; and 2) the same rules apply to everyone entering the state, whether or not they reside in the state.

Early in the pandemic, governors and local officials were sometimes overinclusive and sometimes underinclusive in assessing the risk from travelers. Some measures were reminiscent of Nineteenth Century "shotgun" quarantines, where police patrolled state or local perimeters, seeking to forcibly prevent entry of out-of-state visitors suspected of harboring infection. 
At the same time as he welcomed spring breakers on Florida beaches in 2020, Governor DeSantis of Florida threatened to detain and forcibly quarantine travelers to his state from New York. Later, when infection rates surged in Florida, New York's Governor Cuomo threatened a retaliatory quarantine. Neither was actually put in place. Yet, state and local authorities in Rhode Island, the Outer Banks of North Carolina, and the Florida Keys did set up roadblocks to prevent travelers, even second homeowners, from entering states and select counties. By contrast, there were heartening counterexamples of cooperation between states, like the East Coast and West Coast interstate compacts to create coherent infection containment policies.

Throughout the pandemic, courts have often deferred to governors and mayors on COVID-19 travel restrictions. Of thirty-seven cases challenging travel restrictions filed throughout the pandemic, nearly all were dismissed, settled, or mooted. However, the Supreme Court's recent rulings against gathering restrictions in houses of worship could signal a less deferential judicial posture toward the invocation of state emergency powers by governors. The decisions could establish a special carve-out for religious free exercise claims, or it could be a signal that future challenges to pandemic-related restrictions on individuals and businesses will require more justification than has been required by the high Court until now.

Now, state legislatures are proposing a slew of new laws limiting governors' emergency health powers, either in scope or in duration. Since it's impossible to predict the nature and severity of the next epidemic, limiting executive powers could hamstring effective and rapid action by public health authorities. The COVID-19 pandemic is revealing deficiencies in a federalist approach to public health emergency management. Still unclear is which branch of government (executive or legislative) or level of government (federal, state, or local) can, or should, take decisive action in an emergency.

\section{Federal Travel Restrictions And Other Public Health Powers Within The US}

Given that SARS-CoV-2, and variants of concern, are circulating widely throughout the US, it is and has always been unrealistic to expect a single state, or a group of states, to contain the virus absent federal coordination and action. Since state power is insufficient to address COVID-19 or other national public health emergency — and since states can sometimes act parochially and politically - then where should an emergency public health power to restrict travel reside? An obvious candidate is the CDC.

The CDC has rarely, if ever, prevented travel between or within the states. In 2017, the agency issued a travel advisory for pregnant women recommending against travel to southern Florida where the Zika virus was circulating. But CDC's guidance was not mandatory, simply advisory.

The CDC's may already have the power to restrict domestic travel. The Public Health Services Act of 1944 vests power in the Surgeon General to prevent disease transmission both into the US and between states. CDC "quarantine" regulations were modernized in the waning days of the Obama Administration: The CDC Director may authorize "apprehension, medical examination, quarantine, isolation, or conditional release of any individual for the purpose of preventing the introduction, transmission, and spread of quarantinable communicable diseases." The rule applies to passengers arriving in the US, those who move interstate, and perhaps to some whose 
movements remain intrastate (provided such movement could increase risks of interstate spread of disease).

\section{Federal Power To Impose A National Eviction Moratorium}

Those CDC regulations underlay a significant action taken late last year. On September 4, 2020, then- CDC Director Robert Redfield imposed a national eviction moratorium, as one in five US renters were in arrears. On January 19, 2021, CDC Director Rochelle Walensky extended the moratorium through at least March 31, 2021, determining that evictions could risk SARS-CoV-2 transmission to other states.

CDC's eviction moratorium tests the limits of federal power to prevent interstate spread of infectious diseases. The Biden Administration's recent nationwide mask order for travelrequiring masks on "(i) airports; (ii) commercial aircraft; (iii) trains; (iv) public maritime vessels, including ferries; (v) intercity bus services; and (vi) all forms of public transportation"-may also test that limit, although the federal government has considerable authority in regulating interstate and international carriers.

While the science may support both the eviction moratorium and the mask order, legal challenges are underway already. For example, a Texas District Court ruled that the CDC's nationwide moratorium exceeded its constitutional authority. The ruling will likely be appealed. The outcome of the case could bear on whether new Congressional action is needed to consolidate the CDC's authority in a public health emergency.

\section{Lessons From COVID-19: Principles For This Pandemic And The Next}

The COVID-19 pandemic exposed marked deficiencies of a federalist system, especially as the Trump Administration failed to lead a unified national response. A key lesson is the federal government should take a firmer hand in setting national standards and coordinating pandemic response. Federal control in a public health emergency, as we have seen, is politically charged and susceptible to frequent judicial challenge. Yet, no state acting alone (or even with regional partners) can contain the spread of a highly infectious pathogen while upholding basic human rights.

With wider powers comes the need for safeguards. Going forward, emergency powers should be exercised using the best available evidence, understanding that data are evolving and there will be ongoing scientific uncertainty. Any rule depriving liberty, like travel restrictions or quarantines, should: (1) use the least restrictive means needed to curb the health threat; (2) utilize available testing and tracing protocols as the first line of attack; (3) limit the number of people impacted and the duration of impact to the minimum; and (4) provide procedural rights to challenge application of the rules to individuals and groups. Legislative reforms to emergency powers should be guided by these four principles, and where relevant, reforms should include explicit statements of the principles to fill in any gaps or uncertainties in the law's application. Once clear standards are enacted in state law, courts can enforce them, ensuring that public health agencies appropriately balance public health and human rights. 
As Justice Sandra Day O'Connor once observed in writing about the War on Terror, "A state of war is not a blank check." The peremptory handling of civil rights and liberties in the early months of COVID-19 need to give way to a more orderly and balanced approach as we proceed in the pandemic's second year, and when we encounter subsequent public health emergencies. A good place to start would be Congressional action to preempt conflicting state actions, at least in part; another useful step would be agency action to set health standards, coordinate logistics, and manage the response.

CDC regulations also need updating in line with the principles we offer above. The Model State Emergency Health Powers Act, written in the aftermath of the anthrax attacks, needs modernization, solidifying executive powers to act in an emergency while safeguarding personal freedoms.

Simply limiting federal powers, or curbing emergency powers of governors, is unwise not just for this pandemic, but for the next. We must be conscious of the unpredictability of a future health threat. It might be a novel influenza or coronavirus, but it could be mosquito-borne (like Zika) or waterborne (like polio). We will need the full public health toolkit if we are to avoid the flawed response we have all witnessed at every level of government during the COVID-19 pandemic. The important thing is to provide principles (as outlined above) to ensure that policymakers consider liberty interests as they choose the right tools from that toolkit, rather than severely restricting that choice or eliminating it entirely. It is possible to balance the application of sound public health principles and respect for civil and political rights if both are part of the decision-making matrix at each step of the process.

Authors' Note

The authors want to thank Eric A. Friedman, Michael Huerta, and Sarah Wetter for their extraordinary research and support for this blog post. 